\title{
SHORT COMMUNICATION THE CO-OPERATIVE STUDY OF KUROSHIO (CSK): IS IT BENEFICIAL FOR INDONESIA?
}

\author{
Hanung Agus Mulyadi', Augy Syahailatua ${ }^{2 *}$, Zainal Arifin ${ }^{2}$ \\ 1 Center for Deep-Sea Research, Indonesian Institute of Sciences, J1. Y. Syaranamual Poka, Ambon 97233, \\ Indonesia \\ 2 Research Center for Oceanography, Indonesian Institute of Sciences, J1. Pasir Putih I, Ancol Timur, Jakarta \\ 14430, Indonesia \\ * Correspondence author: <augy.syahailatua@lipi.go.id>
}

\begin{abstract}
The Cooperative Study of Kuroshio and its marginal seas (CSK) is one of the international joint research project conducted in the Western Pacific region. Many Asian countries had been involved in this project from 1965 to1979. Data and information from the CSK are enormous and cover wide-ranging aspects of marine science from the Kuroshio and adjacent regions (e.g. physical aspects, biological aspects and biogeochemical aspects). Indonesia had committed to participate actively in several marine research programs in the area linked to the CSK program by conducting marine research in its internal waters. This essay explained the CSK from biological aspects and Indonesia perspective. During the CSK, biological aspects (e.g. primary productivity, zooplankton biomass, and fisheries) were studied intensively. Indonesia conducted research in internal waters (Natuna Sea and the Java Sea) for oceanography monitoring and fish stock assessment. Participation in the CSK program allowed Indonesia to pursue the establishment of the National Center for Ocean Research (NCOR), develop human capacity building, research properties and standardized all techniques and procedures related to oceanography aspects. After the CSK, Indonesia has continued to conduct marine research linked to the previous study. We learn a lot from the past CSK that a key to succeeding in running this program depending on co-operative spirit, enthusiastic in understanding marine science from the region and enhancing human capacity for doing better marine research.
\end{abstract}

Keywords: CSK program, Indonesia, lesson learned, marine research.

\section{INTRODUCTION}

In the past years, the international joint research program namely Cooperative Study of Kuroshio and its marginal Seas (CSK) has been conducted in the Western Pacific region. Many Asian countries e.g. Japan, China, The Republic of Korea, the Philiphines, Rusia and others had been participated in this program. Physical aspects, biological aspects and biogeochemical aspects are the main focus of the research. Among country have international coordinator to evaluated the program and met anually during 19651977. In 1967, The United nations Educational, Scientific and Cultural Organization (UNESCO) sponsored a meeting among representatives of the Southeast Asian countries to organize and plan marine scientific research related to the CSK program. Further, the series of symposium was held four times during 1968, 1970, 1972 and 1979.

During the CSK program, Indonesia had committed to participate actively in several marine research programs with conducted marine research in its internal waters. In natuna sea, Indonesia was conducted the research study related to temperature, salinity, dissolved oxygen, inorganic phosphate-phosphorus, nitratenitrogen, silicate-silicon, chlorophyll-a, phytoplankton, and zooplankton biomass (Ilahude, 1979). Whereas in Java Sea, Unar (1979) highlighted the annual production of marine fish in Indonesia as 785,300 tons in 1969 and increased to $1,150.000$ tons in 1977. Skipjack and shrimp fisheries had the main marine fishery commodities from 
Indonesia. Linked with CSK program, Indonesia initiated National Center for Ocean Research (NCOR), standardized of procedures for conduct oceanographic research.

After the CSK program termined in 1979, Indonesia continued to conduct marine research e.g. Anambas Expedition in 2002, Indonesia Throughflow / ITF (1996-1998; 2003-2006), and marine eel project in Sulawesi Sea (2010). Finally, this essay will explain (1) the brief notes on the previous CSK program, (2) Indonesian experiences during the past CSK, (3) marine research in Indonesia after the CSK, and (4) what lessons learned for Indonesia. Indonesia would take many benefits from the new CSK program if we have clear marine research program and strategy, establishment of better infrastructures, and strong support by the local and national government.

\section{BRIEF NOTES ON THE PREVIOUS CSK PROGRAM}

The Cooperative Study of Kuroshio

and its marginal seas (CSK; http://iocwestpac.org/page/670.html) is one of the international joint research project conducted in the Western Pacific region, and many Asian countries had been involved in this project from 1965 to1979. The name of Kuroshio was taken from the important ocean current flows in the region, and this current gives much impact on ocean productivity, fishery, climate, and weather. This current shows its significant role for the western Pacific region. Therefore its name was dedicated to the regional marine project in the area.

During the CSK, many studies on marine and fishery aspects were undertaken in the Western Pacific region, and physical oceanography was the main subject to be observed. One significant result from this subject was the climatological map based on ocean current system from tropic to subtropic zones in the region. Besides, aspects of biology and fishery were also concerned in the Kuroshio impacted region. The studies on biology and fishery including primary productivity (Marumo, 1973; Su, 1998; Chen et al., 1998a), zooplankton biomass ( $\mathrm{Su}, 1998)$, fishes and fishery (Ronquillo, 1980) and other marine biotas (Horikoshi, 1980; Ohta, 1980) were studied intensively under several research programs linkage to CSK-1.

From the results of previous studies, we have known the essential impact of Kuroshio on marine productivity in this region. The primary productivity was abundant in the euphotic zone at almost each sampling station during the cruise of RV Hakuho-Maru in the Philippine Sea, Celebes Sea, Sulu Sea, South China Sea and the Indian Ocean from May to October 1972 (Marumo, 1973). Also, the study in the east coast of Taiwan showed a similar condition with the primary productivity ranged from 75.21 to $115 \mathrm{mgCm}-2 \mathrm{~d}-1$ (Su, 1998, Chen et al., 1998a). While concentration and size structure of chlorophyll-a have dynamic pattern varied spatially and seasonally. From the cruise of Hakuho Maru, the concentration of Chlorophyl-a was found in the highest value in between $59-126 \mathrm{mg} / \mathrm{m}^{3}$ with the average as $95 \mathrm{mg} / \mathrm{m}^{3}$ in the Sulu Sea, compared to $34-48 \mathrm{mg} / \mathrm{m}^{3}$ with the mean as $41 \mathrm{mg} / \mathrm{m}^{3}$ in the South China Sea (Marumo, 1973). Whereas from the other study in the South China Sea, during autumn, the average concentration of Chlorophyll-a was $24.94 \mathrm{mg} / \mathrm{m}^{3}$, and nanoplankton with size in between 3-20 $\mu \mathrm{m}$ was abundant, while during spring, the average level of chlorophyll-a was $37.19 / \mathrm{m}^{3}$, and picoplankton with size $<3 \mu \mathrm{m}$ was found dominantly ( $\mathrm{Su}, 1998$; Chen et al., 1998a). Therefore, this region has reasonably high primary production at its euphotic layers.

$$
\text { Zooplankton was studied }
$$
consistently from the Kuroshio and the adjacent regions. Results from plankton observation in the South China Sea showed 429 species identified (Chen et al., 1998b), and copepods were the most abundant (in term of number of species) with 182 
species, followed by Amphipoda (65 sp), Hydromedusae (46 sp), Ostracoda (33 sp), Euphausiacea (32 sp), Thaliacea (7sp) and Decapoda (5 sp). It was also comparable with the results of zooplankton observation from the waters off Mindoro Island and Balayan Bay (the Philippines) that copepods were the significant findings from zooplankton samples (Ordones et al. 1973). Thus, zooplankton in the region was found abundantly in term of number of species, and copepods contributed a significant amount.

A fishery in the Kuroshio impacted region is also well established (Ronquillo, 1980). Many important fishes such as berycoid (Abe, 1972), yellow croaker (Choo, 1970), grey mullet (Tung, 1970), sardine (Kawasaki, 1980; Watanabe et al., 1980), saury (Odate \& Hayashi, 1980), mackerel (Chang, 1972; Tongyai, 1970), scad (Ronqillo, 1972) and tuna (e.g. Fujino, 1972; Hashimoto, 1977; Isa, 1972; Otsu, 1970; Uchida, 1972; Tsuji \& Itoh, 1998) were reported to catch significantly as a commercial fish from this region. Most of these studies on fish and fishery were more focused on their reproductive biology and spawning locations. However, several studies were concerned with population structure, migration pattern, fishing technique, and catch production. Thus, the study results would be useful for fishery management to sustainable fish resources in the region.

\section{INDONESIAN EXPERIENCES DURING THE PAST CSK}

The CSK program was initially designed to focus on the Kuroshio in Japan waters. However, after the organizational meeting in Tokyo (1966) it was highly recommended to extend CSK activities to the marginal seas of the western Pacific region. In May 1967, UNESCO sponsored a meeting among representatives of the Southeast Asian countries to organize and plan marine scientific research related to the CSK program. Since then, Indonesia had committed to participate actively in several marine research programs in the region linked to the CSK program until 1979.

As part of the CSK program, Indonesia conducted marine research in its internal waters, such as the Natuna Sea (part of South China Sea) and the Java Sea using three Indonesian research vessels (RV Burujulasad, RV Jalanidhi, and RV Samudera) (JODC 1971; 1979). The two main aspects of the research conducted were routine oceanography monitoring (Ilahude, 1979) and marine fishery studies, especially fish stock assessment for economically important marine fishes (Unar, 1979).

The marine dynamics study in Natuna Sea was conducted over four consecutive cruises on two research vessels; RV Samudera in February 1971, July 1972, and July 1973 and RV Jalanidhi in December 1971 (Ilahude, 1979). Data and information collected during this study include temperature, salinity, dissolved oxygen, inorganic phosphate-phosphorus, nitrate-nitrogen, silicate-silicon, chlorophyll-a, phytoplankton, and zooplankton biomass. Whereas, Unar (1979) highlighted the annual production of marine fish in Indonesia as 785,300 tons in 1969 and increased to $1,150.000$ tons in 1977. Skipjack and shrimp fisheries had the main marine fishery commodities from Indonesia and probably formed the western Pacific region.

Participation in the CSK program allowed Indonesia to pursue the establishment of the National Center for Ocean Research (NCOR), and to strengthen all resources for marine research including human resources and research facilities (research vessels, laboratories, and equipment). Also, all techniques and procedures for field and laboratory works related to hydrographic and oceanographic research in Indonesia were standardized during the periods of CSK program. Thus, in general, the CSK program had contributed significantly to develop marine 
science not only for the region but also for Indonesia.

\section{MARINE RESEARCH IN INDONESIA AFTER THE CSK}

After CSK project completed in 1979, Indonesia has continued to conduct several marine kinds of research in connection with the previous studies. For example, Anambas Expedition in 2002, Indonesia Throughflow / ITF (1996-1998; 2003-2006), and marine eel project in Sulawesi Sea (2010). These marine research programs were international collaborative works between Indonesia and other countries in the Kuroshio's region.

The Anambas expedition was conducted in March 2002. Collaborative works with scientists from the Southeast Asia who studied marine biodiversity in Anambas and Natuna Islands of the South China Sea. The two-week expedition obtained over 3000 specimens representing a broad diversity of marine plant and animal species including polychaete worms, mollusks, crustaceans, aquatic insects, echinoderms, and fishes. Many were new records for the area, and some were also new to science (Ng et al., 2002).

For the last 20 years, many monitoring programs have measured aspects related to the ITF. Generally, ITF study is located in eastern Indonesia waters where water mass from the Pacific Ocean enters the internal seas of Indonesia, and also in the location where indicated as the exit passages. An international cooperative effort was planned to deploy multi-year mooring buoys to measure velocity, salinity, and temperature of water mass in Makassar Strait, Lifamatola Passage, Lombok Strait, Ombai Strait, and Timor Passage simultaneously. In 1996-1998, The ARLINDO project (Arus Lintas Indonesia, an acronym for ITF) began to study characteristics of Makassar throughflow (Waworuntu et al., 2001). Then, the program called INSTANT (International Nusantara STratification ANd Transport) was established with five countries involved, namely Australia, France, Netherland, the USA, and Indonesia. The INSTANT project has taken three consecutive years, in 2003-2006. A total of 11 deep ocean moorings were deployed within the major Indonesian inflow passages of Makassar Strait and Lifamatola Passage and the exit passage of Lombok Strait, Ombai Strait and Timor Passage (Sprintall et al., 2004). Results of the project indicated the Makassar Strait throughflow composed of North Pacific thermocline and intermediate water from Mindanao current branching. Another source of Makassar throughflow in the surface layer come from the South China Sea and Sulu Sea throughflow involving net westward flow of North Pacific through Luzon Strait with export through the Sibutu Passage into Sulawesi Sea (Gordon et al., 2012) and eastward transport of South China Sea surface water into Java Sea through Karimata Strait (Susanto et al., 2012).

Marine eel project "A study on the spawning migration and reproductive ecology of freshwater eels around Sulawesi Island, Indonesia" was conducted under collaborative works between Indonesia and Japan. Samples of marine eel were collected by using IKMT that operated with Indonesian RV “ Baruna Jaya VII" in 2001 and 2002, and Japanese RV Hakuho Maru in 2010. During the Hakuho Maru cruise, more than 2.000 leptocephali, nine juveniles of 12 anguilliform families, and tuna larvae were sampled.

\section{LESSONS LEARNED FOR INDONESIA}

During the CSK-1, a study on marine biology aspect had conducted in all countries of the region. However, each state decided to have its research focus on this aspect (Marr, 1970; Sugawara, 1972; Takenouti, 1980). Study on the taxonomy of plants and animals in the shallow coastal waters appeared to have much attention from marine scientists in the region. Its 
study aimed to understand the biodiversity and distribution of marine plants and animals. Many marine plants and animals collected in coastal ecosystems, e.g., mangrove forest, seagrass bed, and coral reefs, as well as at the surface, subsurface and, deep water. Then, they were identified as taxa, family, genus or species levels using their key identification books. Subsequently, all samples were deposited for scientific purpose and future examination if needed. Results from studies on marine biology show diversity, distribution and abundance of marine species. Besides, many new records and new species of marine plant and animal were also discovered from these studies; however, lots of unidentified ones have remained.

Lessons learned from the past observations on marine biology in the region indicated that we have to have many taxonomists for doing those works. Some senior taxonomists had no regeneration in their specialized fields on marine plants and/or animals, therefore nowadays, several marine taxa could not be studied well. Also, technological development and many new methods for field and laboratory works are introduced and established. For example, in taxonomy study, using genetic approach is very popular now, and other techniques like mitochondrial DNA testing, genome sequencing, and barcoding of marine organisms could be more trendy topics in marine biology study. In addition, endemic and endangered species have to be studied in more detail. Again, advanced technology and new methodology in observation of marine biology could be challenged and need to pay serious attention for future study on this field.

In the past CSK program, the study on marine biology was very limited to be engaged with physical oceanographic or marine environment dynamic. However, diversity, distribution, and abundance of marine plants and animals have a robust correlation with ocean dynamic. Also, the current issue of climate change, marine pollution, and environmental degradation play a significant role in many aspects of marine life. For example, copepod species of Pontellopsis inflatodigitata was reported prior to an endemic one at the South China Sea; however, it was found at Java Sea (Mulyadi, 2002). Also, modeling in marine biology related to ocean dynamic is quite popular now, and need to be concerned. Therefore, climate change and other global issues should be put in to account for the advanced study on marine biology in the region.

The fishery in the Kuroshio and adjacent region has been recognized; however, it had been limited observed during the CSK-1 in several areas. Fishery studies were more concerned on commercial species, like a sardine, mackerel, and tuna or tuna-like species, and fishery biology was a primary aspect to be examined. Less study on fishery oceanography was conducted in the region, and it will need to be more concerned for the next future observation. Moreover, many marine pelagic species are caught from this region, but not much information related to population structure, stock identification, spawning location, larval fish disperse, migration and distribution patterns, and so on. Thus, there are still a lot of fishery studies that should be taken from this region, especially for the highly migratory species like tuna and tuna-like species.

Tuna is one of the primary essential seafood commodities of most archipelagic countries in the Western Pacific. Currently, tuna in this region is managed under regional fisheries management organization such as Western Central Pacific Commission (WCPFC) which is struggling to reach international consensus on the management of this migratory species. Tuna in this region is estimated as the most abundant which is supported by the high productivity of the coral triangle. Nevertheless, the effort of managing this resource is facing complex challenges since lack of knowledge on stock and population structure. There is no clear record of the oceanography roles in revealing the actual impact on tuna stocks and other marine species regarding their effect on spatial 
behavior, productivity, specific spawning ground and season. It also remains unclear whether oceanography features give influence on the fishery such as the problem of increasing the use of fish aggregating devices (FADs) in some regions.

Given the scale of tuna studies, the information of Kuroshio concerning its role in tuna fisheries is highly prioritized. The complexity of Kuroshio also questions whether there is characteristic in the dynamics of western Pacific tuna that leads to better capacity in understanding to the sustainable tuna fisheries in Western Pacific. Ignoring this information could affect in sustaining the livelihoods of the fishery.

\section{CONCLUSION AND SUGGESTIONS}

Data and information from the CSK-1 are enormous and cover wideranging aspects of marine science from the Kuroshio and adjacent regions. Generally, they comprise all things spatially, from the coastal area to off-shore and open ocean, from the surface to subsurface water and deep-sea, from northern to southern hemisphere, and temporally (seasonally, annually, etc.). Thus, all data and information should be well maintained for our future development programs of marine science and technology in the region and globally.

We learn a lot from the past CSK-1 that a key to succeeding in running this program depending on co-operative spirit, enthusiastic in understanding marine science from the region, and enhancing human capacity for doing better marine research. However, we are now living in the millennium era that this world changes rapidly than before. So, we need new approaches to keeping our CSK existing.

New approaches would be included in the CSK action plan and focus on achieving excellent results not only in marine science perspective but also for improving better life for mankind in the region. Several current issues could be included in CSK next agenda such as food security, renewable energy, and marine ecosystem health. Thus, for CSK new program would be a beneficial for all societies in the region.

The other approach for establishing the new CSK that its activities would be synchronized to several existing projects or programs in the region, for example, Coral Triangle Initiative, Tuna Conservation Program in Western Pacific, and Marine Seascape of WWF. Besides that, the new CSK would have at least one cruise annually on the research vessel for doing research, exchange scientists and training for young marine scientists. Therefore, the new CSK would play a significant role to enhance marine science and technology in the region.

The past CSK remains that data and information from each program or activity are essential, and should be managed carefully. It means that the protocol for data collection and storing should be concerned at the beginning of the new CSK establishment. In addition, management of various data is essential to be considered. Thus, we need to establish also a data center and control for the new CSK.

For the last three decades, marine science and technology have been considerably developed and very much improved. However, each country in the region probably faces different experiences. Sharing advantage marine science and technology among countries may help to reduce the knowledge gaps and enhance capacity and capability of marine scientists in the region. Therefore, the new CSK could be purposed to enhance marine science and also other sciences in general for improving better understanding of science and technology for the future of humanity living and welfare. We think Indonesia would take many benefits from the new CSK program if we have clear marine research program and strategy, establishment and advantages infrastructures, and strongly supported by the local and national government. 


\section{ACKNOWLEDGEMENT}

Authors are thankful to Dr. Anugerah Nontji and Dr. Dwi Susanto for his valuable comments and suggestions. This paper is a part of feasibility study workshop on the CSK 2, Indonesia prespective, funded by Japan Agency for Marine-Earth Science and Technology (JAMSTEC).

\section{REFERENCES}

Abe, T. (1972). Commercial fishing of berycoids and other fishes in previously unfished waters between Japan and the Midaway Islands. In: K. Sugawara (ed), The Kuroshio II: Proceedings of the $2^{\text {nd }}$ Symposium on the Results of the CSK and Adjacent Regions. (pp.525). Tokyo: Saikon Publishing Company Limited.

Chang, K-H. (1972). Studies on Spotted Mackerel Resources of Taiwan. In: K. Sugawara (ed), The Kuroshio II: Proceedings of the $2^{\text {nd }}$ Symposium on the Results of the CSK and Adjacent Regions. (pp. 411-415). Tokyo: Saikon Publishing Company Limited.

Chen, X., Q. Chen, Y. Matsukawa, and K. Kawasaki. (1998a). Distribution and Size Composition of Chlorophyll-a and Primary Production in the Subtropical Waters East of Taiwan. In: T. Asai et al. (ed), Proceeding of Japan-China Joint Symposium on Cooperative Study of Subtropical Circulation System.(pp. 277-288). Nagasaki: Seikai National Fisheries Research Institute, Fisheries Agency of Japan.

Chen, R., J. Lin, Y. Dai, M. Lin, Q. Yang, G. Lin, J. Lin, Y. Hirota, and M. Ishida. (1998b). An Ecological Study on Zooplankton in the Subtropic Circulation Zone. In: T. Asai et al. (ed), Proceeding of Japan-China Joint Symposium on Cooperative Study of
Subtropical Circulation System. (pp. 309-319). Nagasaki: Seikai National Fisheries Research Institute, Fisheries Agency of Japan.

Choo, W II. (1970). A summary report on the yellow croaker in Korea. In: J.C. Marr (ed), The Kuroshio: A Symposium on the Japan Current. (pp. 493-496). Honolulu: East-West Centre Press.

Fujino, K. (1972). Range of skipjack tuna sub population in the Western Pacific Ocean. In: K. Sugawara (ed), The Kuroshio II: Proceedings of the $2^{\text {nd }}$ Symposium on the Results of the CSK and Adjacent Regions. (pp. 373-384). Tokyo: Saikon Publishing Company Limited.

Gordon, A.L., B. Huber, E.J. Metzger, R.D. Susanto, H. Hurlburt, and T.R. Adi. (2012). South China Sea throughflow impact on the Indonesian throughflow. Geophys. Res. Lett. 39, L11602. doi: 10.1029/2012GL052021.

Hashimoto, A. (1977). Report of fish finding (skipjack) survey in the Philippines. Japan International Cooperation Agency. (pp. 151).

Horikoshi, M. (1980). Benthic Biomass and Its Distribution in the Kuroshio and Adjacent Regions. In: Takenouti, A.Y (Ed), The Kuroshio IV: Proceedings of the $4^{\text {th }}$ Symposium for the CSK and Adjacent Region. (pp. 595-601). Tokyo: Saikon Publishing Company Limited.

Ilahude, A.G. (1979). On the hydrology of the Natuna Sea (Southern south China Sea). In Takenouti, A.Y (ed), The Kuroshio IV: Proceeding of the $4^{\text {th }}$ symposium for the cooperative study of the Kuroshio and adjacent regions. Tokyo: Saikon Publishing Co. Ltd.

Isa, J. (1972). The skipjack fishery in the Ryuku Islands. In: K. Sugawara (ed), The Kuroshio II: Proceedings of the $2^{\text {nd }}$ 
Symposium on the Results of the CSK and Adjacent Regions. (pp. 385410).Tokyo: Saikon Publishing Company Limited.

Ishida, M., Y. Hirota, Q-L. Yang, and G-M. Lin. (1998). Young of Pelagic Fishes Transported by the Kuroshio. In: T. Asai et al. (ed), Proceeding of JapanChina Joint Symposium on Cooperative Study of Subtropical Circulation System. (pp. 289-294). Nagasaki: Seikai National Fisheries Research Institute, Fisheries Agency of Japan.

Japan Oceanographic Data Center. (1971). CSK News Letter No 34. Japan: Hydrographyc Department, Maritime Society Agency. (pp. 10).

Japan Oceanographic Data Center. 1979. CSK News Letter No 53. Japan: Hydrographyc Department, Maritime Society Agency. (pp. 33).

Kawasaki, T. (1980). Fluctuation in the Abundance of the Far Eastern Sardine (Sardinops melanosticta) and the Kuroshio. In: Takenouti, A.Y (ed), The Kuroshio IV: Proceedings of the $4^{\text {th }}$ Symposium for the CSK and Adjacent Region. (pp. 806-829). Tokyo: Saikon Publishing Company Limited.

Marr, J.C. (1970). The Kuroshio: A Symposium on the Japan Current. Honolulu: East-West Centre Press.

Marumo, R. (1973). Phytoplankton in the Sea Area of the Southeast Asia. In: The Kuroshio III: Proceedings of the $3^{\text {rd }}$ Symposium for CSK. (pp. 221-259). Bangkok.

Mulyadi. (2002). The calanoid copepod family Pontellidae with notes their group. Treubia, 2, 1-167.

Ng, P. K.L., A.G. Ilahude, N. Sivosathi and D.C.J. Yeo. (2004). Expedition Anambas: an overview of the scientific marine exploration of the Anambas and
Natuna archipelago, 11-12 March 2002. The Raffles Bulletin of Zoology supplement, 11, 1-17.

Odate, S., and K.Hayashi. (1980). Possible Role of the Kuroshio Current in Determining Distribution of Saury in the northwestern Pacific. In: Takenouti, A.Y (ed)., The Kuroshio IV: Proceedings of the $4^{\text {th }}$ Symposium for the CSK and Adjacent Region. (pp. 849-863). Tokyo: Saikon Publishing Company Limited.

Ohta, S. (1980). Photographic Census of the Larger-Sized Epibenthos on the Pacific Coast of Central Japan. In: Takenouti, A.Y (ed)., The Kuroshio IV: Proceedings of the $4^{\text {th }}$ Symposium for the CSK and Adjacent Region. (pp. 602-620).Tokyo: Saikon Publishing Company Limited.

Ordonez, J.A., R.M. Legasto, and N. Metrillo. (1973). Zooplankton Distribution off Mindoro Island and Balayan Bay, Luzon Island, Philippines-South China Sea. In: The Kuroshio III: Proceedings of the $3^{\text {rd }}$ Symposium for CSK. (pp. 285-292). Bangkok.

Otsu, T. (1970). Tagging of skipjack tuna, Katsuwonus pelagis in Palau. In: J.C. Marr (ed.), The Kuroshio: A Symposium on the Japan Current. (pp. 565-568). Honolulu: East-West Centre Press.

Ronquillo, I. A. (1972). Status of the roundscad (Decapterus spp.) catch by purse seine. In: K. Sugawara (ed), The Kuroshio II: Proceedings of the $2^{\text {nd }}$ Symposium on the Results of the CSK and Adjacent Regions. (pp. 417-423). Tokyo: Saikon Publishing Company Limited.

Ronquillo, I.A. (1980). The Contribution of CSK to the Fisheries of the Kuroshio and Its Adjacent Regions. In: 
Takenouti, A.Y (ed), The Kuroshio IV: Proceedings of the $4^{\text {th }}$ Symposium for the CSK and Adjacent Region. (pp. 6785). Tokyo: Saikon Publishing Company Limited.

Sprintall, J., S. Wijffels., A.L. Gordon., A. Ffield., R. Molcard., R. D. Susanto., I. Soesilo., J. Sopaheluwakan., Y. Surachman and H. M. Van Aken. (2004). INSTANT: A new international array to measure the Indonesian throughflow. EOS 85,39, 369-376.

$\mathrm{Su}$, J. (1998). Review of the Work of Chinese Scientists in the China-Japan Joint Programme on the Subtropical Gyre System in the Northwest Pacific. In: T. Asai et al. (ed), Proceeding of Japan-China Joint Symposium on Cooperative Study of Subtropical Circulation System. (pp. 9-12). Nagasaki: Seikai National Fisheries Research Institute, Fisheries Agency of Japan.

Sugawara, K.(ed.), (1972). The Kuroshio II: Proceedings of the $2^{\text {nd }}$ Symposium on the Results of the CSK and Adjacent Regions. (p. 525). Tokyo: Saikon Publishing Company Limited.

Susanto, R.D., A. Ffield, A.L. Gordon, and T.R. Adi. (2012). Variability of Indonesian throughflow within Makassar Strait, 2004-2009. J. Geophys. Res 117, C09013. doi:10.1029/2012JC008096.

Takenouti, A.Y., (1980). The Kuroshio IV: Proceedings of the $4^{\text {th }}$ Symposium for the CSK and Adjacent Region. (pp. 849-863).Tokyo: Saikon Publishing Company Limited.

Tongyai, M.L.P. (1970). Plah In-see, Scomberomorus spp. of Thailand, 1967. In: J.C. Marr (ed), The Kuroshio: A Symposium on the Japan Current. (pp. 557-564). Honolulu: East-West Centre Press.

Tsuji. S., and T. Itoh. (1998). Ecology and Recruitment Fluctuation of Northern Bluefin Tuna. In: T. Asai et al. (ed), Proceeding of Japan-China Joint Symposium on Cooperative Study of Subtropical Circulation System. (pp. 321-330). Nagasaki: Seikai National Fisheries Research Institute, Fisheries Agency of Japan.

Tung, I-H. (1970). Studies on the fishery biology of the grey mullet, Mugil cephalus Linnaeus, in Taiwan. In: J.C. Marr (ed), The Kuroshio: A Symposium on the Japan Current. (pp. 487-504). Honolulu: East-West Centre Press.

Uchida, R. (1970). The skipjack tuna fishery in Palau. In: J.C. Marr (ed), The Kuroshio: A Symposium on the Japan Current. (pp. 596-582). Honolulu: East-West Centre Press.

Unar, M. (1979). Distribution pattern and status of the Indonesian marine fishery resources. In Takenouti, A.Y., (ed), The Kuroshio IV: Proceeding of the fourth symposium for the cooperative study of the Kuroshio and adjacent regions. Tokyo: Saikon Publishing Co. Ltd.

Watanabe, T., K. Honjo, and T. Okutani. (1980). Fluctuation of Population Size of The Japanese Sardine, Sardinops melanosticta (Temminck \& Schlegel) and the Kuroshio. In: Takenouti, A.Y (ed), The Kuroshio IV: Proceedings of the $4^{\text {th }}$ Symposium for the CSK and Adjacent Region. (pp. 830-848). Tokyo: Saikon Publishing Company Limited.

Waworuntu, J.M., S.L. Garzoli and D.B. Olson. 2001. Dynamics of the Makassar Strait. Journal of Marine Research, 59, 313-325. 